\title{
Esterilização por óxido de etileno. I. Influência do meio de esporulação na resistência dos esporos de Bacillus subtilis var. niger*
}

\author{
Ethylene oxide sterilization. I. The influence of sporulation medium in the \\ resistance of the spores of Bacillus subtilis var. niger
}

Terezinha de Jesus A. Pinto** \& Takako Saito**

\begin{abstract}
PINTO, T. de J. A. \& SAITO, T. Esterilização por óxido de etileno. I. Influência do meio de esporulação na resistência dos esporos de Bacillus subtilis var. niger. Rev. Saúde públ., S.Paulo, 26: $379-83,1992$. Tendo por meta a padronização das variáveis influenciando a resistência de esporos empregados no controle do processo esterilizante por óxido de etileno, foram obtidos esporos de Bacillus subtilis var. niger, em meio sólido e líquido sintético de esporulação. Tais esporos, após padronização quantitativa dos 12 lotes obtidos, foram submetidos a exposiçōes subletais como bioindicadores, tendo o papel como suporte. Construiu-se, então, a curva de letalidade característica de cada lote. A análise estatística empregada não evidenciou diferenças entre resistência dos 10 lotes obtidos em meio sólido e os $2 \mathrm{em}$ meio líquido sintético, ressaltando-se a vantagem quanto ao rendimento que caracterizou a primeira metodologia.
\end{abstract}

Descritores: Esterilização, normas. Monitoramento ambiental, métodos. Oxido de etileno. Bacillus subtilis, isolamento.

\section{Introduçăo}

Os estudos sobre a resistência de cepas microbianas ao 6 xido de etileno foram iniciados na década de $1950^{6}$ envolvendo Bacillus cereus var. terminalis, $B$ acillus polymyxa, Bacillus subtilis var. niger e $B a$ cillus megaterium. Relativamente à toxonomia, Church e col. ${ }^{6}$ fazem menção de que esporos bacterianos citado em 1948, como sendo de Bacillus globigii, sejam provavelmente correspondentes ao de Bacillus subtilis var. niger. Segundo o catálogo da "American Type Culture Collection" (ATCC) $1985^{1}$, a nomenclatura da bactéria correspondente ao ATCC 9.372 é Bacillus subtilis var. niger, cuja sinonímia é Bacillus globigii, também conheciđa đá cepa vermelha. A Farmacopéia Norte Americana ${ }^{20}$ adota a nomenclatura de Bacillus subtilis subespécie niger, referindo-se à mesma.

As condições ambientais durante a esporulação

* Parte da tese de Doutorado: "Aspectos Fundamentais na Validaçāo do Monitor Biológico para a Esterilização por Oxido de Etileno", apresentada à Faculdade de Ciências Farmacêuticas da Universidade de São Paulo, em 1991.

* Departamento de Fammácia da Faculdade de Ciências Farmacêtuticas da USP - São Paulo, SP - Brasil.

Separatas/Reprints: T. de J.A. Pinto - Caixa Postal, 3078605340-901 São Paulo-SP, B rasil.

Publicação financiada pela FAPESP. Processo Saúde Coletiva 91/4994-0. bacteriana têm significante importância sobre a resistência ao processo esterilizante, cuja característica deve ser constante. Composição do meio de cultura, bem como tempo e temperatura de incubação e a lavagem dos esporos podem, também, influenciar sobre 0 desempenho do monitor biológico $2,4,11,13,15$.

Quanto aos meios de cultura para esporulação de Bacillus subtilis, tem-se evidenciado a variabilidade entre os meios complexos comercializados, enquanto que resultados melhores têm sido obtidos com meios líquidos de composição quimicamente definida ${ }^{10}$. Dadd ${ }^{7}$ cita, entretanto, as dificuldades de trabalhar com meios sintéticos, com esporulação 50 vezes inferior aos que contem triptona.

O presente trabalho teve como propósito investigar aspectos de rendimento e resistência dos esporos em função da natureza do meio de cultura empregado para a esporulação.

\section{Material e Método}

As características de resistência dos esporos de Bacillus subtilis var. niger obtidos em dois meios de composição diferente foram objeto de estudo frente ao tratamento com óxido de etileno.

Os repiques de manutenção foram em ágar para dosagem de antibióticos $n^{01}$ (Difco), conforme as técnicas recomendadas pela United States Pharmacopeia (USP) XXII ${ }^{21}$. A cultura assim obtida foi 
inoculada em $20 \mathrm{ml}$ de caldo caseína-soja (Difco), com incubação idêntica à anterior. Desta suspensão foram inoculadas alíquotas de $2 \mathrm{ml}$ para cada garrafa de Roux contendo $200 \mathrm{ml}$ de ágar para esporulação (lotes 1 a 10) ou $20 \mathrm{ml}$ para 250 $\mathrm{ml}$ de meio líquido sintético ${ }^{10}$, contido em erlenmeyer (lotes 11 e 12).

Os meios para esporulação apresentavam a seguinte constituição:

\section{- Ágar para esporulação (pH=7,2)}

- extrato de levedura $8,00 \mathrm{~g}$

- caldo nutriente $4,00 \mathrm{~g}$

- sulfato de manganês tetraidratado $0,05 \mathrm{~g}$

- cloreto de cálcio hexaidratado. $0,05 \mathrm{~g}$

- ágar $30,00 \mathrm{~g}$

- água destilada q.s.p. $1.000,00 \mathrm{ml}$

- Meio líquido sintético $(\mathrm{pH}=7,2)^{10}$

- fosfato monoácido de sódio $14,32 \mathrm{~g}$

- fosfato diácido de potássio $3,67 \mathrm{~g}$

- cloreto de amônio $0,53 \mathrm{~g}$

- sulfato de magnésio heptaidratado .... 12,30mg

- sulfato de manganês tetraidratado ....... 2,20mg

- sulfato de ferro heptaidratado.............. 1,10mg

- glicose $0,69 \mathrm{~g}$

- água destilada q.s.p. $1.000,00 \mathrm{ml}$

A incubação das garrafas foi em estufa a $35 \pm$ $2^{\circ} \mathrm{C}$, durante 7 a 14 dias, período em que foi efetuado o acompanhamento diário, através de observação microscópica, do grau de esporulação. $O$ meio líquido sintético foi incubado em estufa, a $35 \pm 2^{\circ} \mathrm{C}$, durante 5 a 7 dias, sob agitação e a comprovação quanto à esporulação foi realizada da mesma forma.

A massa celular de cada garrafa foi retomada com $15 \mathrm{ml}$ de água destilada esterilizada e transferida para erlenmeyer, passando por filtro de 3 camadas de tecido poliéster. $O$ meio líquido foi submetido à centrifugação, a $50,0 \mathrm{~Hz}$, durante 15 min e a massa celular foi retomada em $20 \mathrm{ml}$ de água destilada esterilizada.

O tratamento térmico aplicado aos 12 lotes de suspensão de esporos foi em banho de água $70 \pm$ $2^{\circ} \mathrm{C}$, durante $30 \mathrm{~min}$, seguido de 3 lavagens $\mathrm{s}^{21}$.

A contagem dos esporos de cada lote foi por técnica de semeadura em profundidade após diluição seriada decimal em água destilada, usando ágar caseína-soja (Difco) ${ }^{21}$. Aleatoriamente algumas colônias de diferentes placas referentes a todos os lotes foram submetidas à identificação microscópica após coloração de Gram. Mediante o número de UFC/ml, cada suspensão foi diluída com água destilada a fim de ajustar a concentração para $10^{7} \mathrm{UFC} / \mathrm{ml}$.

A partir de cada lote de suspensão padronizada foram preparados os bioindicadores, distribuindo $0,1 \mathrm{ml}$ para cada suporte de papel de $10 \times 25 \mathrm{~mm}$. Cada tira foi embalada em papel cirúrgico e filme poliéster-polietileno, sendo conservada em refrigerador até o momento do teste.

As condiçб̃es empregadas nos ciclos subletais envolveram umidade relativa de 60 a $70 \%$, temperatura de 45 a $50^{\circ} \mathrm{C}$, concentração de óxido de etileno de $600 \mathrm{mg} / \mathrm{l}$ e tempos de exposição de 5 , 10 e $20 \mathrm{~min}$. $O$ equipamento foi da Fabber-Primar Indústria Ltda., modelo com controle automático e câmara cilíndrica horizontal de $38 \mathrm{~cm}$ de diâmetro e $57 \mathrm{~cm}$ de profundidade.

A contagem dos esporos sobreviventes ao processo foi antecediđa da dispersão das fibras celulósicas em solução fisiológica, por agitação em liquidificador delta eletrônico, em rotação média. A técnica envolvida para a quantificação foi idêntica àquela adotada para padronização da suspensão de esporos e os dados obtidos permitiram a construção das curvas de letalidade e cálculo dos respectivos valores de $D^{19,22}$.

A análise estatística envolveu regressão linear, cuja significância foi avaliada através de teste de Student ${ }^{3}$.

\section{Resultados}

Os dados pertinentes aos 12 lotes de suspensão de esporos estão apresentados na Tabela 1.

Os valores de contagem de UFC/suporte dos 12 lotes de bioindicadores são expressos na Tabela 2, cuja análise estatística, quanto a apresentarem ou não condição de regressão linear, está na Tabela 3.

\section{Discussáo}

O monitor biológico, e em essência o bioindicador, deve apresentar características adequadas e padronizadas, de qualidade de concepção e de processos de preparo nos diferentes aspectos, a fim de que seu desempenho seja confiável.

Dadd e Daley ${ }^{8}$ estudaram, especificamente, a resistência de esporos de Bacillus subtilis var. niger ao óxido de etileno. Esses autores associam a resistência de esporos à espessura da cobertura, assim como à presença de grupos tiólicos. Assim, o elevado número de grupamentos alquiláveis, além da espessa camada de cobertura, evita a morte, uma vez que a alquilação deixa de ser letal.

No presente trabalho, empregou-se para a esporulação, o meio líquido sintético indicado por Hodges e col. ${ }^{10}$, considerado pelos autores como vantajoso frente aos meios sólidos convencionais, pelo elevado índice de esporulação. Kujala e 
Tabela 1. Características dos lotes de suspensão de esporos de Bacillus subtilis var. niger, ATCC 9.372, e dos correspondentes bioindicadores.

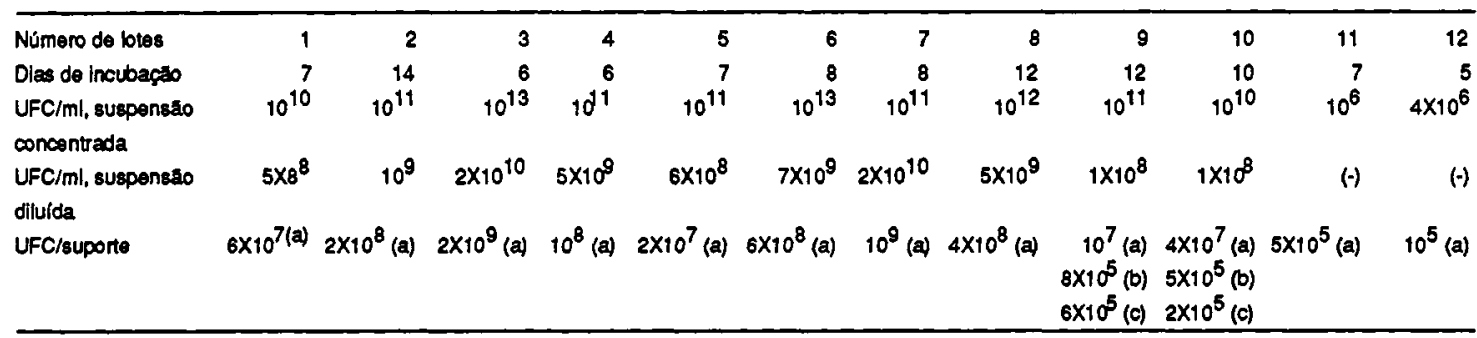

ATCC - "Americam Type Culture Collection"

Tabela 2. Contagem de esporos sobreviventes (UFC/Suporte) nos lotes de bioindicadores após exposiçāo ao óxido de etileno (600 mg/) durante tempos diferentes.

\begin{tabular}{rlllll}
\hline Lote & \multicolumn{5}{c}{ Tempo (minutos) } \\
\cline { 2 - 5 } & 0 & 5 & 10 & 15 & 20 \\
\hline 1 & $6 \times 10^{7}$ & $1 \times 10^{6}$ & $8 \times 10^{4}$ & $8 \times 10^{3}$ & $1 \times 10^{3}$ \\
2 & $2 \times 10^{8}$ & $5 \times 10^{6}$ & $7 \times 10^{4}$ & $6 \times 10^{3}$ & $3 \times 10^{3}$ \\
3 & $1 \times 10^{9}$ & $1 \times 10^{7}$ & $2 \times 10^{4}$ & $2 \times 10^{3}$ & $1 \times 10^{2}$ \\
4 & $1 \times 10^{8}$ & $1 \times 10^{5}$ & $8 \times 10^{2}$ & $1 \times 10^{2}$ & $1 \times 10^{2}$ \\
5 & $2 \times 10^{7}$ & $1 \times 10^{5}$ & $3 \times 10^{3}$ & $5 \times 10^{2}$ & $1 \times 10^{2}$ \\
6 & $6 \times 10^{8}$ & $1 \times 10^{5}$ & $1 \times 10^{3}$ & $8 \times 10$ & $5 \times 10$ \\
7 & $1 \times 10^{9}$ & $5 \times 10^{5}$ & $5 \times 10^{3}$ & $1 \times 10^{2}$ & $1 \times 10^{2}$ \\
8 & $4 \times 10^{8}$ & $6 \times 10^{5}$ & $3 \times 10^{4}$ & $7 \times 10^{2}$ & $1 \times 10^{2}$ \\
9 & $1 \times 10^{7}$ & $1 \times 10^{5}$ & $1 \times 10^{3}$ & $3 \times 10^{2}$ & $5 \times 10$ \\
10 & $4 \times 10^{7}$ & $1 \times 10^{5}$ & $1 \times 10^{3}$ & $1 \times 10^{2}$ & $5 \times 10$ \\
11 & $5 \times 10^{5}$ & $5 \times 10^{4}$ & $1 \times 10^{4}$ & $1 \times 10^{3}$ & $1 \times 10^{2}$ \\
12 & $1 \times 10^{5}$ & $5 \times 10^{3}$ & $1 \times 10^{3}$ & $3 \times 10^{2}$ & $5 \times 10$ \\
\hline
\end{tabular}

Cada valor representa a média de contagens referentes a 30 suportes.

Kauppinen ${ }^{11}$ recomendam, no caso de meio líquido, a utilização de no máximo $30 \%$, em volume, do inóculo em relação ao meio de esporulação, a fim de evitar a perda da sincronia de esporulação. Tal recomendação foi respeitada no presente trabalho quando se utilizou volume de $20 \mathrm{ml}$ como inóculo para $250 \mathrm{ml}$ do meio líquido sintético.

Observou-se, entretanto, que, se de um lado a percentagem de esporulação efetivamente se mantinha desde os primeiros indícios de turbidez, em torno de $100 \%$, o aumento na massa celular se fazia de forma extremamente lenta. Esta constatação conduziu à alteração no planejamento inicial do trabalho, restringindo-se a apenas 2 os lotes em meio sintético. Sabe-se que esta desproporcionalidade é criticável no aspecto estatístico.

Segundo alguns autores ${ }^{10,16,17}$, a recomendação de meios líquidos fundamenta-se no fato de que, quando exauridos certos nutrientes específicos, essa situação induz à esporulação uniforme.

Efetuando-se a cultura em meio sólido obtinhase, no geral, exuberante desenvolvimento de massa microbiana. É bem verdade, entretanto, que nos primeiros dias de incubação se observou tímida evidência de esporulação, que se intensificou no decorrer do acompanhamento. Este fato é coerente, pois há redução no número de forma vegetativa na medida em que a concentração de nutrientes vai-se esgotando ${ }^{14}$.

Por outro lado, a recomendação dos meios líquidos sintéticos reside no fato de que a uniformidade de composição favorece a obtenção de esporos com características idênticas. Apesar disto, ainda são rotineiramente empregados os meios complexos, onde se deve admitir variação lote a lote ${ }^{9}$ Hodges e col. ${ }^{10}$, por exemplo, demonstraram a relação entre diferentes lotes e fa- 
Tabela 3. Análise de regressão linear nos lotes de Bioindicadores.

\begin{tabular}{cccccc}
\hline Lote & $\mathrm{m}$ & $\mathrm{S}_{\mathrm{m}}$ & $\mathrm{r}$ & $\mathrm{D}$ & $\mathrm{t}_{\text {calc. }}$ \\
\hline 1 & $-0,233$ & 0,019 & $-0,989$ & 4,291 & 12,003 \\
2 & $-0,211$ & 0,028 & $-0,973$ & 4,739 & 9,254 \\
3 & $-0,353$ & 0,036 & $-0,984$ & 2,832 & 9,806 \\
4 & $-0,300$ & 0,070 & $-0,922$ & 3,333 & 4,270 \\
5 & $-0,258$ & 0,039 & $-0,966$ & 3,375 & 6,536 \\
6 & $-0,345$ & 0,079 & $-0,929$ & 2,898 & 4,350 \\
7 & $-0,353$ & 0,068 & $-0,948$ & 2,832 & 5,178 \\
8 & $-0,322$ & 0,038 & $-0,979$ & 3,105 & 8,351 \\
9 & $-0,262$ & 0,040 & $-0,965$ & 3,816 & 6,418 \\
10 & $-0,296$ & $-0,952$ & 3,378 & 5,413 \\
11 & $-0,178$ & $-0,977$ & 5,617 & 7,950 \\
12 & $-0,156$ & 0,054 & 6,022 & & 10,093 \\
\hline$m$ & $:$ Coeficiente angular & 0,015 & &
\end{tabular}

bricantes do meio complexo e sintético e a variabilidade dos esporos. Em vista dos resultados, recomendam o uso de meios sintéticos na prática rotineira.

No presente trabalho, o meio líquido sintético contendo ions manganês, cálcio e magnésio como elementos indutores à esporulação contou com a glicose como fator de limitação de crescimento. Segundo Hodges e col. ${ }^{10}$ essas condiçðes permitem $95 \%$ de esporulação. Entretanto, considerando-se, particularmente, os números de UFC/ml nas suspensőes obtidas, e pensando-se na produção de esporos destinada à fabricação de monitores biológicos, quer para a uso proprio, quer para a comercialização de bioindicadores, isto deixa muito a desejar.

O ágar de esporulação, embora não tenha obedecido formulação de outros pesquisadores, respeita a recomendação quanto à adição de íon cálcio, visto ser importante na característica de resistência dos esporos, fato relacionado à biossíntese do dipicolinato de cálcio ${ }^{12,18}$. Quanto ao elevado teor de ágar, teve apenas função prática de maior consistência, facilitando a remoção da massa celular com pouca incorporação de resíduos de fragmentação do meio. Considerou-se como vantajoso o meio sólido em vista de seu elevado rendimento.

Quanto à dispersão no número de esporos, observada pelos dados da Tabela 1, considerou-se tal fato perfeitamente aceitável, haja vista a variação permitida no método oficial da USP XXI ${ }^{21}$, sendo de $10^{4}$ a $10^{9}$ esporos por suporte.

Os valores de tempo de redução decimal (Tabela 3) foram calculados a fim de certificar se todos pertenciam ou não à mesma população. Para cada uma das 12 regressões lineares obtidas a partir de 12 lotes, testou-se a relação de dependência linear entre UFC/suporte e tempo de exposição e se isto refletia a realidade. Aplicou-se, para tanto, individualmente, a hipótese de nulidade $H_{0}: B=0$, onde se passa do coeficiente angular $(\mathrm{m})$ da amostra para $B$ populacional. $O$ teste usando parâmetro estatístico $t$ (student's) permitiu concluir pela rejeição de $\mathrm{H}_{\mathrm{o}} \mathrm{em}$ todos os lotes numa probalidade de $5 \%$ ou menos, evidenciando a significância das regresső̃es.

Observando os dados da Tabela 3, o menor valor de coeficiente de correlação linear $(r)$ é visto no lote 4. Conforme Cerf a não homogeneidade da resistência dos esporos pode conduzir a inexistência de correlação. Apesar disso, excluindo-se fatores como culturas mistas ou mesmo condiçōes adversas de exposição ao agente esterilizante, os 12 valores de $D$ obtidos são oriundos de esporos da mesma população.

\section{Conclusoes}

1. As condiçōes de produção, se em meio sólido ou líquido, não interferem na resistência dos esporos ao gás. 
2. Para a produção industrial de bioindicadores, o meio de esporulação recomendado é o sólido, de composição complexa.

PINTO, T. de J. A. \& SAITO, T. [Ethylene oxide sterilization. I. The influence of sporulation medium in the resistance of the spores of Bacillus subtilis var, niger]. Rev. Saúde públ., S.Paulo, 26: 379- 83, 1992. Some elements influencing the resistance of spores used in ethylene oxide sterilization process control are standardized. Spores of Bacillus subtilis var. niger were produced in chemically defined liquid and solid sporulation media to a tot:l of 12 lots; after standardization of the number of spores, they were challenged by sub-lethal cycles, followed by a lethality study. According to the statistical model applied, there were no differences between the resistance of spores produced in chemically defined liquid and those produced in solid sporulation media. The advantage of the solid sporulation media consists in the larger production of spores.

Keywords: Sterilization, standards. Environmetal monitoring, methods. Ethylene oxide. Bacillus subtilis, isolation.

\section{Referências Bibliográficas}

1. AMERICAN TYPE CULTURE COLLECTION (ATCC). Catalogue of bacteriophages, DNA vector. 16. ed. Rockville, 1985.

2. BORIS, C. \& GRAHAN, G.S. The effect of recovery medium and test methodology on biological indicators. Med. Device Diagn. Ind., 7:43-8, 1985.

3. BRASIL. Leis, decretos, etc. Portaria $n^{9} 80$ de 13 de feverejro de 1986. Diário Oficial da Uniäo, Brasilia, 14 de fev. 1986. Seção I, p. 2471.

4. CAKEBREAD, K. Preparation of a standardized ethylene oxide biological monitor. In: Workshop on Biological Monitoring of Sterilization. 19, Kerkrade, 1986. Pro. ceedings. London, EUCOMED, 1986. p. 174-7.

5. CERF, O. A review. Tailing of survival curves of bacterial spores. J. Appl. Bacteriol., 42:1-19, 1977.

6. CHURCH, B.D.; HALVORSON, H. ; RAMSEY, D.S.; HARTMAN, R.S. Population heterogeneity in the resistance of aerobic spores to ethylene oxide. J. Bacteriol., 72:242-7, 1956.

7. DADD, A.H. Media and environmental conditions for culture of survivors. In: Workshop on Biological Monitoring of Sterilization. 19, Kerkrade, 1986. Proceedings. London, EUCOMED, 1986. p. 187-97.

8. DADD, A.H. \& DALEY, G.M. Role of coat in resistance of bacterial spores to inactivation by ethylene oxide. $J$. Appl. Bacteriol., 53:109-16, 1982.
9. HELLDNGS, J. Acceptance in the Netherlands of physical methods for validation and control of heat sterilization. In: Workshop on Biological Monitoring of Sterilization. $1^{\circ}$, Kerkrade, 1986. Proceedings, London, EUCOMED, 1986. p. 42-4.

10. HODGES, N.A.; MELLING, J.; PARKER, S.J. A comparison of chemically defined and complex media for the production of Bacillus subtilis spores having reproducible resistance and germination characteristics. JPharm. Pharmacol., 32:126-30,1980.

11. KUJALA, T. \& KAUPPINEN, V. Some improvements in the production of Bacillus stearothermophilus spores for sterilization control. Acta Pharm. Fenn., 91:75-83, 1982.

12. LEE, W.H. \& ORDAL, Z.J. Reversible activation for germination and subsequent changes in bacterial spores. $J$. Bacteriol., 85:207-17, 1963.

13. MACKINTOSH, R.D. Sterility testing through bioluminescence measurements. In: Workshop on Biological Monitoring of Sterilization. 192, Kerkrade, 1986. Proceedings. London, EUCOMED, 1986. p. 215-6.

14. MURREL, W.G. The bacterial spore. Apud KUJALA, T. \& KAUPPINEN, V. Some improvements in the production of Bacillus Stearothermophilus spores for sterilization control. Acta Pharm. Fenn., 91:75-83, 1982.

15. PFEIFER, M. \& OTTO, C. The influence of different incubation parameters on the ethylene oxide resistance of spores. In: Workshop on Biological Monitoring of Sterilization. 19, Kerkrade, 1986. Proceedings. London, EUCOMED, 1986. p. 219-21.

16. REICH, R.R. \& GRAHAM, G.S. Performance requeriments for biological indicators in the United States. In: Workshop on Biological Monitoring of Sterilization. $1^{2}$, Kerkrade, 1986. Proceedings. London, EUCOMED, 1986. p. 36-41.

17. RENIKAINEN, M.O. Regulatory authority requirements for biological monitoring in Europe. In: Workshop on Biological Monitoring of Sterilization. 19. Kerkrade, 1986. Proceedings. London, EUCOMED, 1986. p. 4-29.

18. SLEPECKY, R. \& FOSTER, J.W. Alterations in metal content of spores of Bacillus megaterium and the effect on some spore properties. J. Bacteriol., 78: 117-23, 1959.

19. TALLENTIRE, A. Quantitative aspects of microbiological controls in industrial sterilization. In: Gaughran, E.R.L. \& Kereluk, K., eds. Sterilization of medical products. New Jersey, Johnson \& Johnson, 1977. p. 69-86.

20. UNITED STATES PHARMACOPEIA. 21. ed. Rockville, United States Pharmacopeial Convention, 1985.

21. UNTTED STATES PHARMACOPEIA. 22. Ed. Rockville, United States Phamacopeial Convention, 1990

22. WEST, K.L. Ethylene oxide sterilization: a study of resistance relationships. In: Gaughran, E.R.L. \& Kereluk, K., eds. Sterilization of medical products. New Jersey, Johnson \& Johnson, 1977. p. 109-168.

Recebido para publicaçâo em 22.4.1992 Reapresentado em 11.9.1992 Aprovado para publicaçāo em 14.9.1992. 